\title{
精细化管理在建筑工程管理中的应用研究
}

\author{
白志浩* \\ 中铁十七局集团城市建设有限公司 贵州 贵阳 550000
}

摘 要: 建筑行业是我国的支柱产业之一, 为国家建设与发展提供了强大的支撑。近年来, 越来越多的新技术被 用于建筑施工领域中, 人们对建筑质量提出了更高的要求。建筑企业为实现可持续发展的目标, 就一定要加大施工管 理力度, 建设出高质量的建筑产品。精细化管理工作推进阶段, 可以利用标准化与数据化的管理办法, 对工程施工全 过程进行追踪，有针对性地完善管理过程，使建筑工程能够创造出更多的效益。

关键词: 精细化管理; 建筑工程; 成本

DOI: https://doi.org/10.37155/2717-5189-0306-6

\section{1 精细化管理在建筑工程中应用的意义}

1.1 有效保证建筑工程的质量

对于建筑企业而言, 通过构建并运行精细化管理模式, 可严格把控每一个环节的施工质量, 并可使材料管理、人 员管理、进度管理、安全管理等各项工作落到实处，这样便切实保障了建筑工程的整体质量。

1.2 方便建筑工程内部信息的整合

精细化管理可有效整合建筑工程内部的各种信息。目前, 建筑企业主要通过两种途径来提升建筑工程的整体质 量, 一是注重每一个施工细节, 二是对不同层面的信息进行整合。在精细化管理模式下, 各个部门之间加强了信息 交流, 管理者可动态掌握材料配置、设备使用、现场施工、质量验收等方面的信息, 并可以此为依据协调各个阶段 的工作。

1.3 协助建筑企业在施工活动中创造出更多的经济效益

这主要得力于精细化管理能降低工程建设成本, 科学调配各种材料、机械设备, 将建材浪费量降到最低, 最大限 度地提升原材料的利用率。

1.4 提高企业的核心竞争力

在如今社会经济不断高速发展的环境下, 企业想要有效提高自己的竞争力, 就需要充分提高自己的收益, 并且完 善自己的管理制度, 这样才能够更加稳定长久地发展下去。精细化的管理方式可以在一定程度上提高企业的经济效 益，在实际的管理工作当中，可以采用一些责任制度来调动员工的积极性，从而能够提高企业的整体水平和质量。

\section{2 精细化管理的介绍}

精细化管理是近些年发展起来的一种新的管理学理念, 其以传统管理学管理模式为基础, 细化整个管理过程的分 工情况, 进而降低项目管理成本, 提升管理工作质效。在精细化管理工作推进阶段, 清晰确定各方职责, 确保管理责 任能落实到位, 真正实现责权统一。以上目标的实现并不是一蹴而就的, 需要管理者将自身岗位职责发挥到最大化, 协调不同部门之间的关系，整体提升各管理流程的效率，进而实现预定的管理目标 ${ }^{[1]}$ 。

\section{3 我国建筑施工管理的现状}

3.1 施工监管在建筑工程中未得到重视

最近几年, 我国建筑行业保持了较快的发展速度, 但一些建筑企业在扩大发展规模的同时, 却忽略了管理水平的 提升。调查发现, 现阶段我国尚未构建完善的建筑监督体系, 能够达到行业自律要求的建筑企业总体占比并不高。因 此建筑工程在施工阶段容易出现多种问题, 而这些问题几乎都与施工监管的缺失紧密相关。在施工阶段应用精细化管 理模式，可使有关人员真正落实现场施工监管。

*通讯作者：白志浩，男，汉族，1984.11，内蒙古，本科，中级工程师。 


\section{2 监理效果差}

施工现场负责监理工作的工作人员的专业水平以及监理工作质量都能够直接影响工程管理工作质量，特别是进行 施工进度管理工作时, 监理能够产生更加关键的影响。然而, 现如今负责监理工作的工作人员无法满足精细化管理 工作对监理的需求, 很多有效控制施工质量, 进度控制工作也存在不足。为了提高监理工作水平, 企业以及政府部门 都制定了许多相应的制度以及措施，然而在进行实际的管理工作时并没有发挥足够的作用。许多监理工作人员水平较 低, 企业也很难招聘到高水平的专业监理, 因此负责施工监理的工作人员很难做好监理工作, 不利于企业在工程中获 得足够高的利润，而且会影响企业在社会上的信誉，导致企业无法顺利发展。

\section{3 建筑工程施工质量偏低}

施工质量是影响建筑施工效率及工程使用寿命的主要因素之一，故而在工程管理实践中应把工程建设质量管理作 为首要任务。但具体施工阶段, 影响建筑质量的因素较多, 主要包括: (1) 建筑工程的作业环境与工法; (2) 成本 管理方法的科学性不足, 施工方一味地追求低成本, 短缩工期, 采购劣质材料或简化部分工序, 进而对工程质量形成 不良影响; (3) 既有管理机制不健全, 施工活动中, 管理者没有将自身的作用充分发挥出来, 岗位权责未能落到实 处，这是部分工程管理作用缺失的主要原因。

\section{4 合理应用精细化管理的有效措施}

4.1 构建一套完善的精细化管理机制

建筑工程管理水平的提升, 必须以精细化管理机制的构建与完善为依托。为此, 建筑企业应当将材料检验、人员 操作、设备运行、质量验收等纳人精细化管理的范畴。除此之外, 建筑企业还必须成立专门的管理小组, 层层落实精 细化管理的责任, 同时要求每一名员工都要积极参与精细化管理工作, 只有形成齐抓共管的局面, 才能保障建筑工程 的整体质量 ${ }^{[2]}$ 。

\section{2 加强对施工现场人员的精细化管理}

工程施工需要大量的人力支持, 包括负责工程建设的施工人员以及操控机械设备的技术人员、负责工程管理的管 理人员、负责施工材料采购的工作人员等都可以在工程施工中发挥重要作用。因此, 企业为了提高工程管理质量, 发挥精细化管理作用, 要严格管理企业的所有工作人员, 确保可以有效发挥管理效果, 保障工程质量。首先, 企业要 让所有工作人员都能够清晰了解自己的工作任务以及责任, 在进行负责工程管理工作的工作人员的选择时要选择一些 有较强工作能力的专业人员, 为工程每一个环节工作的顺利提供保障。在进行技术人员的选择时, 企业要根据工程设 计, 选择能够满足工程需求的专业技术人员，并且要保证技术人员的专业水平能够达到企业要求，在遇到各种专业问 题能够沉着应对并解决, 促进工程施工的顺利进行, 保证工程质量能够满足企业要求。在选择负责工程施工的施工团 队时企业要对他们的专业技术能力以及专业素养进行严格审核, 确保他们的责任心以及专业水平都能够满足企业的施 工需求。并且要对这些施工人员进行专业培训，让他们了解并掌握工程中需要的各种专业施工技术。

4.3 施工质量的精细化管理

\subsection{1 建设健全质量检测验收标准}

建筑企业应在内部尽早建设一套完善的质量验收标准，并严格执行应用这项标准，进而公平、合理地测评、判断 建筑工程的最后质量，确保完工后的建筑质量能符合国家及广大业主的要求。

\subsection{2 建设追踪机制}

现代建筑企业应合理应用互联网、计算机等技术，做好建筑工程建设质量的数据分析工作，及时发现质量缺陷问 题, 尽早处理, 最大限度地提升工程施工的精细化管理水平, 采用适宜的方法持续创新施工管理过程和方法, 最大限 度地提升建筑工程质量管理效率 ${ }^{[3]}$ 。

\section{4 有效加大政府监管力度}

作为政府管理部门，除了可以远程监测建设现场的安全性之外，还可以扩展到质量管理领域。可以通过监控系统 对施工进行抽查, 在给抽查人员带来极大便利的同时, 也能确保施工的准确性, 同时要充分了解监控的重点内容, 开 展随机抽查, 进而更加反映出真实性 ${ }^{[4]}$ 。通过视频监控, 能够有效促进政府部门对施工的监管, 进而使工程质量得到 保障。 


\section{5 结束语}

综上所述，企业高层管理领导必须重视精细化管理策略的实施，在施工过程中的各个环节使用精细化的管理方式 严格进行工程管理，确保每一环节的施工都能满足企业要求，保障工程质量能够达到业主的要求。

\section{参考文献:}

[1]曲全鹏.精细化管理在建筑工程管理中的应用[J].建筑工程技术与设计,2019,(33):2750.

[2]刘晨.精细化管理在建筑工程管理中的应用[J].装饰装修天地,2019,(22):59.

[3]王伟.建筑工程施工管理中精细化管理的应用[J].装饰装修天地,2019,(22):327.

[4]韩雪.精细化管理在建筑工程管理中的应用[J].建材发展导向(上),2019,(11):314. 